\title{
SEJARAH PERUBAHAN SOSIAL MASYARAKAT AGRARIS AKIBAT PEMBANGUNAN WADUK DI BANJARNEGARA, JAWA TENGAH
}

\author{
Kuntoro Boga Andri \\ Balai Pengakajian Teknologi Pertanian (BPTP) Jawa Timur \\ kuntoro@gmail.com
}

\begin{abstract}
ABSTRAK
Penelitian bertujuan untuk mengetahui sejarah dari pengaruh perubahan lingkungan ekologis pada masyarakat agraris yang terjadi akibat pembangunan waduk. Metode penelitian yang dilakukan adalah metode kualitatif yang menghasilkan data deskriptif dari orang-orang dan perilaku yang diamati. Hasil dari penelitian memperlihatkan pembangunan proyek PLTA Panglima Besar Soedirman telah merubah secara mendasar masyarakat agraris serta budaya pertanian di lokasi penelitian. Hilangnya lahan berarti juga merubah lahan usaha bagi mereka. Mereka yang beralih mata pencaharian ke sektor perikanan dihadapkan banyak kendala. Perkembangan sektor perdagangan dan jasa sangat dipengaruhi oleh situasi desa yang ada. Perubahan juga mengakibatkan memudarnya lembaga tradisional yang biasa hidup dalam masyarakat agraris. Juga terjadi degradasi dalam birokrasi Desa dan perubahan tipe ekonomi keluarga dari basis ke tipe upahan. Anggota keluarga yang tadinya memiliki sikap familinisme kuat berubah ke individualisme.
\end{abstract}

Kata kunci: Perubahan Sosial, Masyarakat Agraris, Adaptasi, Banjarnegara

THE HISTORY OF SOCIAL CHANGE OF AGRARIAN COMMUNITY WHICH CAUSED BY THE DAM DEVELOPMENT INBANJARNEGARA, CENTRAL JAVA

\section{ABSTRACT}

The study was conducted to observethe history of the effect of environmental change toward an agrarian community as a result from the damconstruction. This study used qualitative method, which present the descriptive data of the observed people and the societies. It was revealed the dam of Panglima Besar Soedirman had a significant effect of the change of agriculture communities in the studied area. Most people, moved from the agricultural to fisheries and service sector. Some problems occurred in the community that change their occupation to the fisheries sector as well as the trading and the service sectors uncertainly. The changed also ensuring losts of the agricultural institution as well as degradation and declining on the activities of village bureaucracy. There were a transformationof the family income type from the basis type to be the hired worker type, and relationship from familial type to be individual type.

Key words: Social Change, Agrarian Community, Adaptation, Banjarnegara

\section{PENDAHULUAN}

Soemardjan (1991), menyatakan bahwa perubahan sosial adalah segala perubahan pada lembaga-lembaga kemasyarakatan di dalam suatu masyarakat, yamg mempengaruhi sistem sosialnya, termasuk didalamnya nilai-nilai, sikapsikap dan pola-pola perilaku diantara kelompok-kelompok dalam masyarakat. 


\section{Agriekonomika, ISSN 2301-9948

Tekanan pada definisi tersebut terletak pada lembaga-lembaga kemasyarakatan sebagai himpunan pokok manusia, perubahan-perubahan dimana kemudian mempengaruhi segi-segi lainnya dari struktur masyarakat tersebut.

Perubahan sosial terjadi karena keinginan manusia untuk menyesuaikan diri dengan keadaan sekelilingnya ataupun disebabkan oleh ekologi, dimana bahwa persoalan perubahan sosial adalah produk dari interaksi banyak faktor (Kusumaningrum, dkk., 2015). Faktor faktor yang menyebabkan terjadinya perubahan sosial sumbernya mungkin ada yang terletak di dalam masyarakat itu sendiri dan ada yang terletak di luar masyarakat itu, yaitu yang datangnya sebagai pengaruh dari masyarakat lain, atau dari alam sekitarnya (Susanto, 1977; Soemardjan dan Soemardi, 1964).

Beberapa dekade terakhir ini konversi lahan pertanian untuk berbagai bermacam kegiatan non pertanian terus berlangsung. Menurut Harsono dalam Abidin (1997), alih fungsi lahan ini merugikan karena: (1) mengurangi potensi memproduksi beras nasional, (2) menyulitkan tenaga kerja sektor pertanian, (3) mendorong urbanisasi. Perubahan penggunaan lahan pertanian ke penggunaan non pertanian juga akan menyebabkan hilangnya kelembagaan tradisional. Pada masyarakat pedesaan agraris yang mata pencahariannya tergantung pada lahan pertanian tumbuh berbagai kelembagaan tradisional dan itu semua akan hilang bersama perubahan penggunaan lahan yang terjadi. Hal itu menunjukkan perubahan penggunaan lahan dari pertanian ke non pertanian tidak hanya berdampak ekonomi tetapi juga berdampak sosial, yaitu hilangnya fungsi kelembagaan (Firdaus, 1995). Perubahan penggunaan lahan dapat merubah bentuk hubungan kerja dan bentuk penguasaan tanah, yang pada gilirannya akan membawa perubahan pada kesempatan kerja, tingkat pendapatan dan kesejahteraan diantara penduduk desa (Kasryno, 1984).

Disisi lain, kebutuhan air tentu saja semakin meningkat. Upaya pengembangan sektor strategis yang membutuhkan sumberdaya air diantaranya adalah sektor industri, pertanian, perikanan, pariwisata, rumah tangga dan perdagangan. Keberadaan proyek PLTA dengan pembuatan waduk dan bendungannya tentu akan memberikan dampak terhadap masyarakat. Perubahan pada lingkungan ekologis berpengaruh terhadap kehidupan sosial bagi yang langsung terkena ataupun yang berada disekitar proyek. Sebagian besar kaum tani pada daerah genangan waduk harus merelakan sawah dan tanah garapan yang selama ini menjadi tumpuan mata pencaharian. Kondisi tersebut memaksa mereka untuk beradaptasi terhadap perubahan yang terjadi, dan berpengaruh pada sistem sosial masyarakat. Juga terhadap nilai sosial, norma sosial, pola perilaku, organisasi dan susunan lembaga serta lapisan dalam masyarakat. Aspek aspek perubahan sosial tersebut akan di telaah dalam penelitian ini.

\section{METODE PENELITIAN}

Penelitian difokuskan pada sejarah kasus Desa Wanadadi yang berada $14 \mathrm{~km}$ sebelah barat kota Banjarnegara, Jawa Tengah. Desa yang merupakan ibu kota Kecamatan Wanadadi ini memiliki kondisi yang sangat baik untuk pertanian sawah dengan tanah alluvial-nya yang subur. Penentuan lokasi dipilih secara purposive dengan pertimbangan desa ini termasuk wilayah agraris yang paling banyak terkena dampak pembangunan waduk baik dilihat dari jumlah penduduk yang terkena proyek maupun luas lahan yang tergenang. Penelitian ini 
memfokuskan analisa dokumen dan perubahan terjadi pada tahun-tahun dimana perubahan sosial akibat proyek waduk terjadi (tahun 1980 sampai dengan 1997).

Metode penelitian yang dilakukan adalah metode kualitatif yang menghasilkan data deskriptif dari orang-orang dan perilaku yang diamati. Informasi langsung selain dari penduduk desa yang dipilih sebagai responden juga dari hasil wawancara dengan tokoh masyarakat atau pejabat instansi yang terkait. Untuk melihat perkembangan keadaan masyarakat Desa Wanadadi pada kurun waktu yang ingin diteliti, penulis juga menggunakan dokumen data monografi/data potensi desa yang ada tahun-tahunsebelum pembangunan waduk $(1980,1982,1984)$ dan setelah pembangunan selesai (1993 dan 1997) sebagai dasar analisa. Sumber data sekunder lainnya diperoleh dari lembaga-lembaga/instansi di wilayah penelitian.

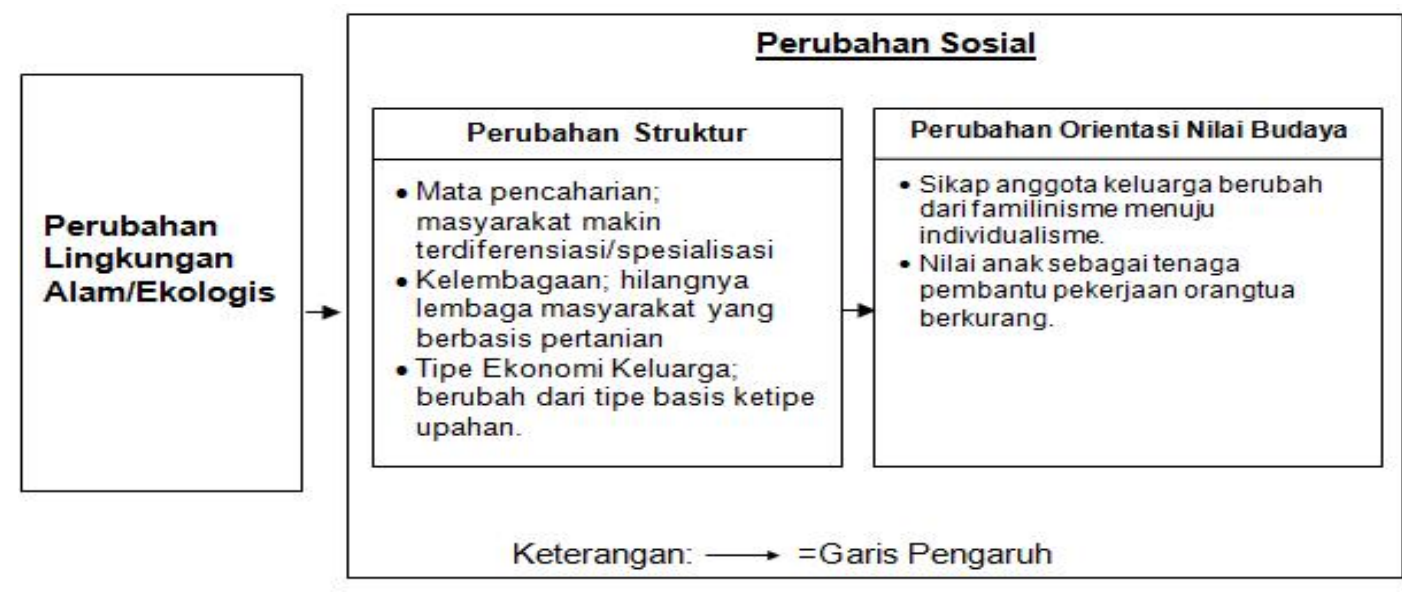

Sumber: Data Primer Diolah, 2010

\section{Gambar 1 \\ Kerangka Pemikiran Penelitian}

Alur pikir penelitian ini seperti tertera dalam Gambar 1, dimana pembangunan proyek waduk PLTA menyebabkan terjadinya perubahan pada lingkungan alam/ekologis. Digenanginya sawah dan tanah garapan sebagian besar penduduk dan putusnya jalan utama yang menghubungkan desa mereka dengan pusat kota mengakibatkan masyarakat dihadapkan pada kondisi lingkungan baru, dan harus menyesuaikan diri dengan perubahan yang terjadi. Kondisi ini berakibat terjadinya proses perubahan sosial masyarakat baik menyangkut stuktur maupun orientasi nilai budaya. Perubahan struktur antara lain terjadi pada mata pencaharian penduduk dimana masyarakat makin terdiferensiasi/spesialisasi. Selain itu perubahan lainnya ialah hilangnya lembaga tradisional masyarakat agraris. Juga terjadi perubahan tipe ekonomi keluarga dari tipe basis ke tipe upahan. Perubahan yang terjadi dalam nilai budaya masyarakat antara lain sikap anggota keluarga dari familinisme menuju pada individualisme. Serta nilai anak sebagai tenaga untuk membantu pekerjaan orang tua pun berubah.

\section{HASIL DAN PEMBAHASAN \\ Perubahan Struktur Demografis}

Gejala perubahan sosial dapat menyangkut perubahan struktur sosial seperti jumlah penduduk dan tingkat pendidikan, atau perubahan pola serta peranan dari suatu masyarakat. Menurut Sajogyo (1985), perubahan struktur masyarakat adalah perubahan dalam hubungan interaksi antar orang, antar organisasi atau antar 


\section{Agriekonomika, ISSN 2301-9948 e ISSN 2407-6260 \\ Volume 5, Nomor 1}

komunitas dan berkaitan sangat erat dengan berbagai masalah yang timbul dalam beragam masyarakat, baik yang berhubungan dengan masalah ekonomi, sosial-budaya maupun masalah lingkungan hidup. Dari Tabel 1 terlihat pada tahun 1993 jumlah penduduk desa Wanadadi mengalami penurunan dibanding tahun 1982 dan 1984. Hal itu merupakan akibat langsung dari pembangunan waduk pada tahun 1985-1989. Pembangunan tersebut menyebabkan banyak penduduk yang bermigrasi akibat rumah atau lahannya tergusur. Sehingga jumlah penduduk Desa periode 1985-1993 lebih kecil dibanding tahun 1982 atau 1984.

Akan tetapi ada fenomena lain dari rentang perkembangan penduduk tahunan yang cenderung meningkat pada periode tahun 1993-1997 (1,91\%) dibanding periode 1982-1984 (1,37\%). Kondisi tersebut menggambarkan terjadi peningkatan perkembangan jumlah penduduk yang lebih pesat setelah proyek berakhir. Hal ini selain disebabkan oleh banyaknya penduduk yang kembali ke Wanadadi setelah proyek selesai juga karena berkembangnya sektor jasa dan perdagangan pada periode tersebut. Juga pada perkembangan penduduk dari tiap golongan usia (dan jenis kelamin), dapat dianalisa dependency ratio (rasio beban tanggungan) pada tahun-tahun tersebut. Angka dependency ratio tahun 1982 ialah 100,34; dan menjadi 97,64 pada tahun 1984; selanjutnya 71,05 pada tahun 1993 dan 65,63 untuk tahun 1997. Hal ini menggambarkan golongan usia angkatan kerja yang makin membesar sehingga memerlukan tambahan jumlah lapangan kerja.

Tabel 1

Perkembangan Penduduk Menurut Kelompok Umur dan Jenis Kelamin Desa Wanadadi

\begin{tabular}{|c|c|c|c|c|c|c|}
\hline \multicolumn{2}{|c|}{ Kelompok Umur } & $0-14$ & $15-54$ & $>55$ & Total & (\%) \\
\hline \multicolumn{2}{|r|}{$\mathrm{L}$} & 641 & 729 & 100 & 1470 & \multirow{4}{*}{1,37} \\
\hline \multirow[t]{3}{*}{1982} & $P$ & 628 & 737 & 102 & 1467 & \\
\hline & Jumlah & 1269 & 1466 & 202 & 2937 & \\
\hline & $\mathrm{L}$ & 658 & 721 & 99 & 1478 & \\
\hline \multirow[t]{2}{*}{1984} & P & 638 & 806 & 96 & 1540 & \multirow{8}{*}{1,91} \\
\hline & Jumlah & 1296 & 1527 & 195 & 3018 & \\
\hline \multirow{3}{*}{1993} & $\mathrm{~L}$ & 401 & 927 & 174 & 1502 & \\
\hline & P & 421 & 721 & 175 & 1317 & \\
\hline & Jumlah & 822 & 1648 & 349 & 2819 & \\
\hline \multirow{3}{*}{1997} & $\mathrm{~L}$ & 382 & 912 & 218 & 1512 & \\
\hline & P & 390 & 924 & 215 & 1529 & \\
\hline & Jumlah & 772 & 1836 & 433 & 3041 & \\
\hline
\end{tabular}

Sumber: Data Primer Diolah, 2010

Tabel 2, terlihat peningkatan persentase penduduk yang menamatkan pendidikan pada semua tingkat (SD, SLTP, SLTA dan Perguruan Tinggi) dari tahun 1982 sampai 1993. Namun disayangkan makin besarnya prosentase masyarakat yang tidak sekolah/buta aksara (dari 7,2\% tahun 1982 dan 0,3\% tahun 1984 menjadi $13,3 \%$ pada tahun 1993). Fenomena diatas menggambarkan makin sadarnya sebagian golongan masyarakat akan pentingnya pendidikan, akan tetapi disisi lain terdapat sebagian golongan yang kesulitan menyekolahkan anaknya pada pendidikan formal. 
Tabel 2

Perkembangan Pendidikan Masyarakat Desa Wanadadi

\begin{tabular}{lrrr}
\hline Jenis Pendidikan & \multicolumn{1}{c}{$1982(\%)$} & \multicolumn{1}{c}{$1984(\%)$} & $1993(\%)$ \\
\hline Belum Sekolah & $561(19,1)$ & $492(16,3)$ & $391(13,9)$ \\
Tidak Tamat SD/Sederajat & $548(18,7)$ & $727(24,1)$ & $99(3,5)$ \\
Tamat SD/Sederajat & $935(31,8)$ & $1090(36,1)$ & $1137(40,3)$ \\
Tamat SLTP/Sederajat & $372(12,7)$ & $382(12,7)$ & $402(14,3)$ \\
Tamat SLTA/Sederajat & $294(10,0)$ & $308(10,2)$ & $368(13,0)$ \\
PerguruanTinggi/Sederajat & $14(0,5)$ & $11(0,3)$ & $48(1,7)$ \\
Tidak Sekolah/Buta Aksara & $213(7,2)$ & $8(0,3)$ & $374(13,3)$ \\
Total & $2937(100)$ & $3018(100)$ & $2819(100)$ \\
\hline
\end{tabular}

Sumber: Data Primer Diolah, 2010

Menurut Soentoro (1983), apabila tanah pertanian sudah tidak ada (tidak mampu) memberi pekerjaan bagi masyarakat setempat, mereka akan memberikan reaksi terhadap lingkungan untuk mencari jenis pekerjaan di sektor non pertanian. Tentang kecenderungan makin meningkatnya masyarakat pedesaan yang bekerja di sektor non pertanian ada beberapa dugaan. Pertama tenaga kerja tersebut terlempar dari sektor pertanian. Dugaan kedua, mereka ditarik oleh terbukanya kesempatan kerja di luar sektor pertanian dengan pendapatan yang lebih baik. Dugaan lain, di pedesaan telah terjadi pergeseran nilai yang memandang rendah bekerja sebagai buruh tani, terutama tenaga muda tampaknya enggan bekerja di sektor pertanian.

Secara umum terdapat 5 lima golongan utama mata pencaharian penduduk desa. Perkembangan lima golongan utama pekerjaan penduduk sebelum dan setelah pembangunan waduk PLTA tertera dalam Tabel 3. Dalam struktur mata pencaharian masyarakat, perubahan yang paling jelas terlihat ialah menurunnya masyarakat yang bergelut di sektor pertanian pada tahun 1993 di banding tahun 80an. Keadaan tersebut nyata terlihat pada tahun 1984 dengan turun drastisnya prosentase penduduk yang bekerja pada sektor pertanian, sewaktu waduk mulai dibangun. Namun tahun 1997 peningkatan jumlah penduduk yang bekerja pada sektor pertanian menjadi 12,8\%. Ini karena sejak tahun 1993 pihak PLTA memperbolehkan penduduk menggarap tanah milik PLTA pada bangunan pelimpah darurat (emergency spillway) yang tidak terpakai. Mereka menggunakan tanah tersebut untuk tanaman semusim, padi serta kolam ikan. Terdapat sekitar 60 petani penggarap tanah emergency spillway di desa ini. Keberadaan waduk ternyata hanya menarik 3,3\% (21 jiwa pada tahun 1993) dan 5,3\% (48 Jiwa pada tahun 1997) untuk bekerja di sektor perikanan, dimana sebagian terhalang alasan modal, keterampilan dan resiko.

Dari Tabel 3 terlihat proporsi kerja sektor perdagangan relatif stabil pada periode 80-an hingga tahun 1997. Sempat terjadi peningkatan tajam di sektor ini di masa awal proyek (dari 11,4\% tahun 1980 menjadi 38,7\% pada tahun 1984). Hal ini terjadi karena maraknya suasana desa saat itu dan besarnya ganti rugi tanah yang masyarakat terima yang bisa digunakan sebagai modal. Tetapi terlihat dalam perjalanananya hanya beberapa orang saja yang bertahan (tahun 1993 menurun menjadi $24,6 \%$ ). Sektor ini nampaknya memang menjadi milik orang-orang tertentu saja. Hal itu bisa dimaklumi karena untuk bisa masuk sektor ini diperlukan pengalaman, keterampilan, keberanian dan modal yang cukup besar yang tidak dimiliki oleh sebagian besar mantan pekerja di sektor pertanian. 


\section{Agriekonomika, ISSN 2301-9948 \\ April, 2016 e ISSN 2407-6260 \\ Volume 5, Nomor 1}

Tabel 3

Perubahan Struktur Mata Pencaharian Penduduk

\begin{tabular}{lrrrr}
\hline Jenis & \multicolumn{1}{c}{1980} & \multicolumn{1}{c}{1984} & \multicolumn{1}{c}{1993} & \multicolumn{1}{c}{1997} \\
Pekerjaan & \multicolumn{1}{c}{ (Jiwa) } & \multicolumn{1}{c}{ (Jiwa) } & \multicolumn{1}{c}{ (Jiwa) } & \multicolumn{1}{c}{ (Jiwa) } \\
\hline Pertanian & $408(42,4 \%)$ & $248(25,7 \%)$ & $60(9,5 \%)$ & $116(12,8 \%)$ \\
Perikanan & $0(0,0 \%)$ & $0(0,0 \%)$ & $21(3,3 \%)$ & $48(5,3 \%)$ \\
Industri & $5(0,5 \%)$ & $23(2,4 \%)$ & $2(0,3 \%)$ & $8(0,9 \%)$ \\
Jasa & $70(7,3 \%)$ & $254(26,3 \%)$ & $390(61,2 \%)$ & $434(48,0 \%)$ \\
Perdagangan & $110(11,4 \%)$ & $374(38,7 \%)$ & $157(24,6 \%)$ & $300(33,0 \%)$ \\
Lainnya & $369(38,4 \%)$ & $67(6,9 \%)$ & $7(1,1 \%)$ & - \\
Jumlah & $962(100 \%)$ & $966(100 \%)$ & $637(100 \%)$ & $906(100 \%)$ \\
\hline
\end{tabular}

Sumber: Data Primer Diolah, 2010

Desa kasus sebagai ibukota kecamatan dengan infrastruktur yang tersedia memiliki potensi yang besar sebelum masa pembangunan bendungan PLTA. Wilayah ini merupakan jalur penghubung (simpang) beberapa kecamatan disekitarnya menuju ibukota kabupaten. Tak aneh bila sektor perdagangan menjadi sumber mata pencaharian banyak warganya di masa itu. Terlebih ketika proyek pembangunan PLTA dimulai, banyak orang luar yang datang masuk ke daerah ini sehingga menambah semarak pasar disini. Komoditi pertanian dari daerah sekitar selain barang kebutuhan rumah tangga mendominasi komoditi yang diperdagangkan. Terdapat lembaga perbankan berupa BPR (Bank Surya Yudha) yang melihat potensi warga yang sangat memerlukan jasa penyimpanan uang dan pinjaman modal usaha. Tetapi kondisi ini berubah ketika proyek berakhir, dimana waduk yang ada memutus jalan terdekat dari Kecamatan Wanadadi ke kota Kabupaten Banjarnegara. Ini mengakibatkan kegiatan perdagangan di desa dan kecamatan sekitar pada periode tahun 1984 sampai dengan 1993 menurun. Daerah ini tidak lagi menjadi arus lalu lintas masyarakat kecamatan sekitar menuju ibukota kabupaten. Lokasi desa juga menjadi relatif sukar dijangkau (dikelilingi waduk). Keadaan ini berakibat banyak warga yang berpindah dari kegiatan perdagangan ke sektor lain.

Kegiatan yang paling berkembang dalam periode 1980-1997 ialah jasa. Pada tahun 1980 hanya $7,3 \%$ dari tenaga kerja bekerja di sektor ini, kemudian tahun 1993 meningkat mencapai $61,2 \%$ dan selanjutnya pada 1997 prosentase pekerja jasa turun menjadi 48,0\% dengan banyaknya penduduk yang kembali bertani dengan menggarap tanah emergency spillway. Fenomena ini terjadi karena sektor jasalah yang memungkinkan menampung mereka khususnya mantan buruh tani ketika mereka kehilangan lahan pekerjaan. Banyak pekerjaan pada bidang ini yang tidak membutuhkan keterampilan dan pengetahuan khusus. Bekerja sebagai kuli bangunan, buruh kasar dan jasa angkutan merupakan pekerjaan yang kini banyak dilakukan. Sebagian masyarakat bahkan merantau hingga ke luar daerah. Kota-kota besar seperti Bandung dan Jakarta menjadi alternatif "ladang penghidupan" pengganti bagi mereka. Disana bahkan ada yang menetap hingga beberapa bulan sebelum kembali pulang. Ketika proyek pembangunan PLTA berlangsung banyak terbuka peluang kerja dan aktivitas ekonomi bagi masyarakat. Pada saat konstruksi proyek maupun setelah pasca proyek, penduduk disini dilibatkan dalam pembuatan bendungan dan waduk dan kegiatan lain yang timbul akibat adanya proyek tersebut seperti: (1) Petugas keamanan/satpam, supir, tukang batu, tukang kayu, tukang las, dan buruh pekerja lainnya. (2) Pelayanan jasa; menyediakan tempat-tempat pemondokan, pembantu rumah tangga serta warung/rumah makan. (3) Usaha 
dagang dalam rangka memenuhi kebutuhan tenaga kerja pada proyek. (4) Pada kegiatan transportasi (angkutan lokal) dan ojek.

\section{Adaptasi Masyarakat dan Perubahan Kesejahteraan}

Adanya adaptasi dalam suatu masyarakat khususnya dalam kesempatan berusaha di pedesaan tidak dapat dianalisa secara tersendiri karena hal tersebut berhubungan erat dengan masalah tingkat kesejahteraan. Kesejahteraan seseorang tergantung dari curahan waktu dan tingkat pendapatan dalam satuan waktu diterima. Adapun tingkat pendapatan dalam satuan waktu tersebut dipengaruhi oleh tingkat pendidikan dan ketrampilan dan sumber-sumber non tenaga yang dikuasai. Lebih jauh menurut Mubyarto (1985), makin tinggi pendidikan atau ketrampilan dan makin besar sumber non tenaga yang dikuasai, makin tinggi pendapatan per satuan waktu yang diterima. Sementara yang terlihat bahwa keterampilan tenaga-tenaga muda masih kurang, penyebab utama meningkatnya pengangguran dan ini harus dikaitkan dengan pendidikan formal yang mereka terima, bahkan lulusan sekolah kejuruan pun seringkali harus diberi pendidikan ketrampilan tambahan oleh perusahaan yang memberinya pekerjaan.

Hal tersebut diatas sesungguhnya sudah dipahami dan diantisipasi oleh pengelola proyek dan pemerintah daerah setempat. Sebelum selesainya proyek, pemerintah daerah (bekerja sama dengan pihak PLTA) mengadakan beberapa kali penyuluhan tentang pengelolaan dan pemanfaatan sumberdaya waduk. Pelatihan berupa cara membudidayakan ikan dalam jaring terapung maupun keterampilan lainnya dengan maksud masyarakat dapat memanfaatkan uang hasil ganti rugi yang mereka terima dengan baik. Pihak PLTA sejak awal telah memberikan pemahaman kepada masyarakat bahwa kelak akan ada waduk yang dapat dimanfaatkan untuk budidaya perikanan dan selanjutnya juga terus berusaha menarik minat masyarakat untuk membudidayakan ikan dengan beberapa proyek percontohan. Ketika bangunan fisik waduk belum rampung, beberapa orang petani setempat (delapan orang dari Desa Wanadadi) telah diberi pelatihan perikanan air tawar, dengan biaya pemerintah, selain praktek lapang pemeliharaan ikan di waduk Jatiluhur (praktek budidaya ikan dengan jaring terapung dan pemagaran). Pelatihan tersebut diberikan tahun 1984 sedangkan fisik waduk PLTA baru ada tahun 1987. Rentang waktu yang panjang antara pelatihan dengan saat mempraktekannya tidaklah membuahkan hasil yang efektif. Bahkan kini warga yang mengikuti pelatihan tersebut justru tidak melakukan kegiatan perikanan. Bentuk adaptasi jenis pekerjaan yang terjadi pada beberapa orang warga yang dipilih sebagai responden dapat dilihat pada Tabel 4.

Sebagian besar responden (70\%) yang semula bergerak dalam sektor pertanian beralih pada sektor jasa, perdagangan dan perikanan. Hanya 4 orang $(20 \%)$ responden yang masih bergelut dalam sektor pertanian. Bila kita amati keempat responden tersebut merupakan masyarakat lapisan bawah. Pada responden juga terlihat adanya diferensiasi pekerjaan. Yang tadinya sebagian besar hanya memiliki satu jenis pekerjaan (10 orang) atau dua jenis pekerjaan (6 orang), sekarang 9 responden memiliki dua macam pekerjaan dan bahkan terdapat 2 orang yang memiliki 3 macam pekerjaan. Hal itu menggambarkan kondisi responden yang tidak bisa lagi menggantungkan hidup hanya dari satu jenis pekerjaan saja dan harus mencari pekerjaan lainnya/tambahan agar kebutuhannya tercukupi. 


\section{|| Agriekonomika, ISSN 2301-9948 \\ April, 2016 e ISSN 2407-6260 \\ Volume 5, Nomor 1}

Tabel 4

Sejarah Adaptasi Jenis Pekerjaan pada Responden

\begin{tabular}{|c|c|c|}
\hline Inisial & Pekerjaan SebelumProyek & $\begin{array}{c}\text { Pekerjaan Setelah Proyek } \\
\text { Selesai }\end{array}$ \\
\hline \multicolumn{3}{|c|}{ Lapisan bawah } \\
\hline AW & Pertanian, Jasa & Pertanian, Jasa, perikanan \\
\hline IA & Pertanian & Jasa, Perdagangan \\
\hline$J L$ & Pertanian, Jasa & Pertanian, Jasa \\
\hline $\mathrm{JO}$ & Pertanian & Pertanian, Jasa \\
\hline M D & Pertanian & Perikanan, Jasa \\
\hline MU & Pertanian & Pertanian, Jasa \\
\hline P D & Jasa & Jasa \\
\hline \multicolumn{3}{|c|}{ Lapisan menengah } \\
\hline $\mathrm{DT}$ & Pertanian & Perikanan \\
\hline MJ & Pertanian & Perikanan \\
\hline ST & Perdagangan, Jasa & Perikanan, Perdagangan \\
\hline SS & Belum bekerja & Jasa \\
\hline SP & Pertanian, Jasa & Perikanan, Jasa \\
\hline \multicolumn{3}{|c|}{ Lapisan atas } \\
\hline $\mathrm{AM}$ & Pertanian & Perdagangan, Perikanan \\
\hline IS & Jasa & Jasa \\
\hline $\mathrm{IH}$ & Pertanian & Tidak bekerja \\
\hline IU & Belum bekerja & Jasa \\
\hline $\mathrm{MH}$ & Pertanian, Jasa & Tidak bekerja \\
\hline S A & Jasa, Pertanian & $\begin{array}{l}\text { Jasa, Perikanan, } \\
\text { Perdagangan }\end{array}$ \\
\hline$S G$ & Belum bekerja & Jasa \\
\hline UP & Pertanian, Perdagangan & Jasa, Perdagangan \\
\hline
\end{tabular}

Sumber: Data Primer Diolah, 2010

Keterangan: Penggolongan Lapisan Berdasarkan Luas Kepemilikan Lahan.

Tabel 5

Persepsi Perubahan Kesejahteraan setelah Adanya Proyek PLTA

\begin{tabular}{lc}
\hline Perubahan Kesejahteraan & $\mathrm{n}=20$ \\
\hline Meningkat & 3 \\
Tetap & 8 \\
Turun & 9 \\
\hline
\end{tabular}

Sumber: Data Primer Diolah, 2010

Perubahan mata pencaharian dari tiap lapisan juga menjadi fenomena menarik. Hanya pada lapisan bawah terdapat mereka yang tetap terjun pada sektor pertanian (4 dari 7 responden lapisan bawah) sedangkan lapisan menengah dan atas meninggalkan sektor tersebut. Selain itu terlihat pada semua reponden lapisan bawah kini bekerja juga pada sektor jasa (sebagian besar sebagai buruh atau pekerja kasar). Pada lapisan menengah 4 dari 5 responden beralih pada sektor perikanan, sedangkan pada lapisan atas hampir sebagian besar dari mereka terjun ke sektor jasa disamping perdagangan dan perikanan. Tentu kecenderungan ini sangat dipengaruhi oleh modal, ketrampilan dan pengetahuan yang dimiliki oleh responden. Keberadaan proyek memang dirasakan berpengaruh terhadap tingkat kesejahteraan seperti yang tertera dalam Tabel 5. 
Hampir separuh responden menyatakan kesejahteraannya menurun akibat adanya proyek PLTA (dari semua lapisan), meskipun terdapat tiga orang menyatakan kesejahteraannya membaik. Sebagian besar dari mereka yang menyatakan kesejahteraannya menurun adalah yang tadinya menggantungkan kehidupannya dari sektor pertanian baik sebagai pemilik sawah ataupun penyakapdan petani penggarap (baik dari lapisan atas menengah maupun bawah). Pada tahun-tahun awal (sekitar lima tahun pertama) sebagian masyarakat memang merasakan manfaat dan hasil yang sangat memuaskan dari budidaya maupun penangkapan ikan di waduk. Dari budidaya ikan tersebut petani bisa memperoleh keuntungan yang berlipat besarnya hanya dalam waktu relatif singkat (sekitar 3-4 bulan) melalui pembesaran ikan. Sampai akhirnya pada tahun 1991 terjadi kendala besar pertama ketika secara serempak ikan mati dalam semalam karena kondisi air waduk yang tiba-tiba berubah. Padahal hampir seluruhnya membudidayakan ikan tersebut dengan intensif dimana menghabiskan modal yang cukup besar dan tinggal menunggu saat panen. Tentu saja banyak petani yang mengalami kerugian, bangkrut, kehabisan modal dan beberapa terlilit hutang.

Hal ini menjadi titik tolak mundurnya budidaya jaring terapung. Hanya beberapa petani yang memiliki kemauan dan modal besar serta ekonomi mapan yang berani melanjutkan budidaya ini, meskipun dilakukan tidak seintensif dulu. Mereka mengakui budidaya ikan di jaring terapung memang sangat beresiko dan sangat perlu ketelatenan dan keuletan yang tinggi. Juga kurang berkembangnya usaha ini dikarenakan pasang surutnya air waduk yang tidak bisa diprediksi oleh petani. Ini merepotkan pemilik jaring yang harus memindahkan jaring terapungnya dari lokasi yang semula surut ke tengah danau yang mempunyai kedalaman air cukup. Di sisi lain hasil tangkapan ikan dari waduk yang tadinya sangat diharapkan sebagai pengganti sumber penghasilan memberikan hasil yang kurang memuaskan. Pada lima tahun pertama adanya waduk seorang nelayan dengan 10 jaring tariknya setiap hari dapat memperoleh tangkapan ikan antara 10-20 kg. Namun setelah itu hasil tangkapan dari waduk cenderung terus menurun.

Tidak berkembangnya budidaya ikan dalam jaring di lokasi penelitian disebabkan oleh beberapa hal: (1) Faktor modal; untuk dapat mengembangkan sebuah kolam jaring terapung membutuhkan biaya yang cukup besar. Apalagi sebagaian besar bahan yang diperlukan untuk pembuatan jaring terapung ini seperti bambu, drum bekas, jaring nilon dan sebagainya semuanya didatangkan dari luar daerah. (2) Belum yakinnya keuntungan yang diperoleh (resiko gagal), khususnya bagi pemilik modal yang pas-pasan, sebab gagal berarti hilangnya seluruh modal dan sulit untuk dapat bangkit kembali memiliki modal yang cukup untuk memulai usaha. (3) Sulitnya memperoleh bibit ikan, dan bibit masih didatangkan dari luar (Purwokerto, Purwonegoro, Klaten dan Yogyakarta). Hal ini menyebabkan mahalnya harga bibit, selain banyak yang mati atau rusak dalam perjalanan. (4) Material pakan ikan yang semuanya didatangkan dari daerah lain sehingga mahal. (5) Masih minimnya ketrampilan/pengetahuan petani dalam budidaya jaring terapung menyebabkan rendahnya produksi ikan. Disamping menejemen yang kurang baik dan sulitnya aspek pemasaran.

\section{Perubahan Pada Kelembagaan Desa}

Kelembagaan dipandang penting mengingat kelembagaan inilah yang mendasari keputusan untuk produksi, investasi dan kegiatan ekonomi lainnya yang dibuat oleh seorang individu atau sebuah organisasi dalam konteks sosial atau dalam hubungan dengan pihak lain. Perubahan dalam kelembagaan akan merubah gugus oportunis yang dihadapi oleh para pelaku ekonomi sehingga keragaan 


\section{Agriekonomika, ISSN 2301-9948

ekonomi seperti output, kesempatan kerja, kemiskinan, kerusakan lingkungan, distribusi pendapatan dan lain-lain akan berubah. Perubahan dalam teknologi, preferensi, pendapatan dan lain-lain menuntut adanya perubahan dalam kelembagaan. Kelembagaan yang ketinggalan jaman akan menghambat atau menimbulkan dampak negatif yang tidak diinginkan seperti pengangguran, ketimpangan pendapatan, kemiskinan, kerusakan lingkungan dan lain-lain.

Kelembagaan pedesaan dapat berupa kelembagaan-kelembagaan penguasaan tanah, hubungan kerja dan perkreditan. Jika ekonomi pasar di suatu pedesaan kurang berkembang, maka hubungan kelembagaan akan memegang peranan yang lebih penting dalam transaksi, baik untuk faktor produksi maupun untuk produknya (Kasryno, 1984). Lembaga dalam masyarakat desa ada yang bersifat asli dari adat kebiasaan yang turun temurun tetapi ada pula yang baru diciptakan baik dari dalam maupun dari luar masyarakat desa.Lembaga adat yang penting dalam pertanian misalnya pemilikan tanah, jual beli dan sewa menyewa tanah, bagi hasil, gotong royong, koperasi, dan arisan. Lembaga-lembaga ini mempunyai peran tertentu yang diikuti dengan tertib oleh anggota masyarakat desa (Mubyarto, 1989). Menurut Nasution dalam Firdaus (1995), alih fungsi lahan sawah yang banyak dan sering terjadi dalam pembangunan, dapat menyebabkan hilangnya kelembagaan tradisional yang telah berakar dalam kehidupan masyarakat.

Mengenai macam kelembagaan yang ada di Desa Wanadadi sebelum dan setelah adanya proyek PLTA dapat dibedakan antara kelembagaan ekonomi, kelembagaan pemerintahan desa serta kelembagaan sosial dan keluarga. Kelembagaan ekonomi adalah lembaga yang sengaja dibentuk oleh masyarakat untuk mendukung kelancaran aktivitas ekonomi masyarakat, usahatani dan bisnis serta meningkatkan produksi. Lembaga ekonomi yang ada di daerah penelitian antara lain: Koperasi Unit Desa, Perkumpulan Petani Pemakai dan Pengguna Air (P3A), serikat pekerja (SPSI), Kelompok Pendengar Siaran Pedesaan, Kelompok Tani dll.

Lembaga pemerintahan desa merupakan lembaga formal yang mengurusi masalah kemasyarakatan desa, administrasi dan birokrasi serta menjalankan fungsi dan informasi dari lembaga pemerintah diatasnya. Sedangkan kelembagaan sosial adalah kelembagan yang dibentuk secara resmi ataupun tidak, yang diakui dan diikuti dengan baik oleh masyarakat desa dalam kaitannya dengan hubungan sosial kemasyarakatan. Lembaga semacam ini memang kadang tidak memiliki aturan secara tertulis tetapi apabila ada anggota yang tidak memenuhi ketentuan yang dianggap norma oleh masyarakat akan dikenakan sanksi sosial pula. Lembaga semacam ini contohnya rukun kematian, kegiatan ibu-ibu PKK, pengajian, dan termasuk didalamnya keluarga dan sistim kekerabatan. Perubahan yang terjadi pada struktur masyarakat dan adaptasi yang terjadi dalam lingkungan sosial sebagian besar penduduknya tentu berpengaruh pula dalam kelembagaan masyarakat di daerah penelitian. Perubahan aktifitas yang terjadi pada kelembagaan akibat perubahan ekologi yang terjadi di desa ini ditampilkan dalam Tabel 6 . 
Tabel 6

Perubahan Aktifitas Lembaga pada Masyarakat Desa Wanadadi

\begin{tabular}{|c|c|c|c|}
\hline Lembaga & $\begin{array}{c}\text { Sebelum } \\
\text { Adanya PLTA }\end{array}$ & $\begin{array}{c}\text { Setelah } \\
\text { Adanya PLTA }\end{array}$ & Keterangan \\
\hline \multicolumn{4}{|l|}{ Kelembagaan ekonomi: } \\
\hline KUD & Aktif & Tidak aktif & Tkt. kecamatan \\
\hline BKK (Badan Kredit Kecamatan) & Tidak aktif & Aktif & Tkt. kecamatan \\
\hline P3A & Aktif & Tidak aktif & \\
\hline Kelompok Tani & Aktif & Tidak aktif & \\
\hline SPSI & Tidak aktif & Aktif & Tkt. kecamatan \\
\hline Kelompok Tani dan Nelayan & Belum ada & Aktif & \\
\hline Koperasi Simpan Pinjam & Tidak aktif & Tidak aktif & \\
\hline Paguyuban Pedagang Pasar & Aktif & Aktif & \\
\hline $\begin{array}{l}\text { Kelompok penggarap } \\
\text { emergancy spillway }\end{array}$ & Belum ada & Aktif & \\
\hline $\begin{array}{l}\text { Kelembagan Pemerintahan } \\
\text { Desa: }\end{array}$ & & & \\
\hline Kantor dan aparat desa & Aktif & Tidak aktif & \\
\hline LMD dan LKMD & Aktif & Tidak aktif & \\
\hline Kelembagaan sosial: & & & \\
\hline PKK & Tidak aktif & Aktif & \\
\hline Kelompok siaran pedesaan & Aktif & Tidak aktif & \\
\hline Lumbung desa RW & Aktif & Tidak aktif & \\
\hline Rukun kematian & Aktif & Aktif & \\
\hline Arisan & Aktif & Aktif & (RT/RW/Desa) \\
\hline Jumpitan beras & Aktif & Tidak aktif & \\
\hline Pengajian & Aktif & Aktif & \\
\hline Sambatan & Aktif & Aktif & \\
\hline
\end{tabular}

Sumber: Data Primer Diolah, 2010

\section{Kelembagaan Ekonomi}

Dengan hilangnya lahan pertanian maka hilang pulalah kelembagan ekonomi tradisional dan sistim sosial yang telah lama hidup dalam masyarakat agraris. Sistem sakap tanah pertanian kini jarang dipergunakan lagi, penggunaan sistim bawon saat panen pun sudah memudar. Kini mereka yang tetap bertahan dalam pertanian pun akan menggarap sendiri tanah yang mereka miliki atau menggunakan tenaga upahan bila membutuhkan. Untuk panen mereka juga menggunakan tenaga sendiri atau mengupah orang lain atau "ditebas"/dijual langsung kepada pengepul. Hal ini berlaku pula bagi penggarap lahan di emergency spillway. Hal mencolok setelah adanya proyek PLTA adalah makin menguatnya organisasi atau kelompok-kelompok yang bergerak/berorientasi pada sektor jasa dan perdagangan disamping perikanan. Serta memudarnya lembaga traditional masyarakat pertanian. Kenyataan ini terlihat dengan makin mengakarnya organisasi (bila kita amati dari jumlah anggota, kegiatan/aktifitas yang dilakukan serta keterikatan anggota terhadap organisasi/kelompok yang diikuti) seperti SPSI (Serikat Pekerja Seluruh Indonesia) Ranting Wanadadi, Paguyuban Pedagang Pasar, Badan/lembaga keuangan dan perkreditan serta Kelompok Minasari yang bergerak dalam kegiatan perikanan. Kondisi tersebut berimbas dengan pasifnya kegiatan beberapa organisasi yang tadinya sangat menonjol dalam masyarakat sebelum adanya proyek seperti yang terlihat pada Tabel 6. 


\section{Agriekonomika, ISSN 2301-9948

Dari Tabel 6, terlihat lembaga ekonomi yang biasanya hidup dalam masyarakat agraris seperti kelompok tani dan P3A berubah dari aktif menjadi tidak aktif bersama dengan tercabutnya sebagian besar mereka dari kegiatan pertanian sawah akibat pembangunan proyek PLTA. Sedangkan untuk lembaga-lembaga seperti KUD dan Koperasi simpan pinjam memang masih ada, tetapi sama sekali tidak ada aktifitas berarti yang dilakukan. Perubahan yang terjadi dalam struktur masyarakat tentu saja diikuti dengan perubahan dalam lembaga masyarakatnya. Timbulnya suatu lembaga dalam masyarakat tentu karena hal tersebut merupakan kebutuhan pada masyarakat itu. Dan tentu saja suatu lembaga menghilang atau menjadi tidak aktif lagi dalam masyarakat karena lembaga tersebut tidak bisa memenuhi tuntutan kebutuhan dari warganya. Sebagian besar responden yang ikut dalam kelompok yang ada beralasan mereka bergabung pada suata kelompok karena merasakan adanya keuntungan yang didapat. Rasa aman karena adanya pengayom/pelindung terhadap usaha yang dilakukan atau kemudahan memperoleh pinjaman uang/barang (meskipun dalam jumlah terbatas) adalah salah satu alasannya.

\section{Kelembagaan Sosial dan Keluarga}

Dalam konteks kelembagaan sosial, aktifitas dari kelompok masyarakat yang masih terus hidup dan berkembang di desa ini umumnya adalah kegiatan keagaman (pengajian, rukun kematian dII) ataupun kegiatan rutin dua mingguan atau bulanan dari ibu rumah tangga dan remaja wanita berupa arisan dan lembaga informal yang kini menonjol yaitu PKK (Pembinaan Kesejahteraan Keluarga) Desa Wanadadi. Menurt Sajogyo (1982), Pada masyarakat dengan sistem perekonomian yang agraris, keluarga dan rumah tangga merupakan produksi, konsumsi, reproduksi serta interaksi sosial-ekonomi. Dalam hal ini harus diperhatikan bentuk dan fungsi serta mengerti akan perilaku dalam rumah tangga itu. Fungsi serta struktur kekerabatan merupakan indikator penting dalam menelaah perubahan dari perilaku keluarga. Dalam masyarakat pedesaan, anggota dari grup kekerabatan yang mempunyai pengaruh besar terhadap anggota keluarga inti: menghambat inisiatif individu serta mobilitas horisontal/geografis dan juga menghambat jenjang karir serta mobilitas dalam pekerjaan. Gejala tersebut merupakan manifestasi dari pada tradisionalisme. Para ahli kemasyarakatan mengasumsikan ciri-ciri tersebut sebagi domestik, pribadi dan intim (Sajogyo, 1982). Sejalan perkembangan masyarakat, menurut Gutman dan Montgomery dalam Sajogyo (1982), terdapat perubahan dalam pola keluarga pekerja serta adanya pertumbuhan dalam urbanisasi. Perubahan nampak pada norma yang berkaitan dengan komposisi dan besar keluarga. Selain itu terdapat pendekatan yang ingin mengungkapkan perubahan sikap yang terjadi dalam masyarakat modern; sikap familinisme (pola sikap lama) berubah ke sikap individualisme (pola sikap modern). Sikap individualisme menunjuk kepada memudarnya ikatan kekerabatan dengan segala kewajiban individu sebagai anggota keluarga terhadap grup yang lebih besar.

Adanya proyek PLTA di daerah kasus juga berpengaruh terhadap bentuk tipe ekonomi keluarga serta nilai anak. Pada masyarakat agraris di daerah penelitian, sebelum adanya proyek, tipe ekonomi keluarga khususnya para pemilik lahan pertanian adalah basis, dalam arti keluarga berfungsi sebagai produsen yang menghasilkan produk pertanian untuk kebutuhan sendiri atau dijual. Kondisi tersebut berubah setelah hilangnya lahan pertanian. Keluarga yang berganti mata pencaharian baik pada kegiatan jasa maupun perdagangan berarti telah beralih ke tipe ekonomi keluarga upahan. Dalam arti mereka memperoleh pendapatan untuk menghidupi keluarganya dari menjual jasa/tenaga kepada masyarakat. Memang 
pada warga yang sejak dulu telah berdagang, bekerja pada kegiatan jasa dan tidak memiliki sawah, tipe keluarga mereka adalah tetap upahan. Tetapi pada buruh tani perubahan yang terjadi adalah upahan dari sektor pertanian menjadi upahan pada sektor jasa atau perdagangan. Dalam tipe ekonomi keluarga basis juga terdapat perubahan pada warga yang semula merupakan petani pemilik sawah kemudian menjadi produsen perikanan.

Hal lain yang terjadi akibat adanya pembangunan bendungan PLTA pada keluarga di daerah ini ialah banyaknya suami yang pergi bekerja ke luar desa untuk bekerja. Sebagian dari mereka pergi ke kota-kota disekitar seperti Banjarnegara, Wonosobo dan Purwokerto bahkan banyak pula yang bekerja hingga Bandung dan Jakarta dalam jangka waktu yang relatif lama. Keadaan ini menyebabkan perubahan sikap pada anggota keluarga yang tadinya memiliki sikap familinisme berubah ke sikap yang cenderung individualisme. Hal ini bisa terlihat dari mulai renggangnya ikatan-ikatan kekeluargaan yang ada dengan segala kewajiban individu sebagai anggota keluarga terhadap grup yang lebih besar yaitu grup kerabatnya. Juga dengan adanya fenomena kepala keluarga/anggota keluarga lainnya yang dalam beberapa bulan pergi keluar kota untuk mencari nafkah menyebabkan lemahnya alokasi integrasi dan ekspresi diantara anggota keluarga sendiri. Hal tersebut juga sangat potensial untuk menyebabkan terjadinya disorganisasi keluarga dalam bentuk terganggunya komunikasi dalam keluarga. Permasalahan dapat timbul jika sang istri tidak bisa memegang peranan yang ditinggalkan suaminya atau dia mengalami kesulitan dalam melaksanakan peran tersebut.

Dinegara-negara berkembang, kerja merupakan bagian penting dari kehidupan sehari-hari mayoritas anak-anak dan remaja pedesaan. Dalam masyarakat pedesaan yang berstratifikasi yang ditandai dengan ketidaksamaan dalam kekayaan dan kekuasaan serta diferensiasi sosial-ekonomi yang mengiringinya, generalisasi itu tidak berlaku bagi semua anak dan remaja, tapi sekurang-kurangnya berlaku bagi mayoritas anggota rumah tangga petani kecil, petani marjinal dan petani yang tak bertanah (White dan Tjandraningsih, 1991). Nilai seorang anak baik ditinjau dari sudut ekonomi maupun bukan ekonomi (kepuasan, rasa aman dan lain sebagainya) diduga erat berhubungan dengan pola fertilitas yang dilaksanakan suatu keluarga. Menurut Espenhade dalam Sumitro (1981), nilai anak bagi orangtua dapat dipandang dari segi ekonomis maupun non ekonomis, karena selain anak dapat membantu menambah pendapatan rumah tangga juga anak berharga karena mendatangkan kebahagiaan, mendatangkan kebanggaan dan kasih sayang. Menurut Sumitro (1981), Masalah keuangan adalah alasan yang terpenting baik dalam keuntungan maupun dalam kerugian dari anak bagi orangtua.

Pada nilai anak terdapat perkembangan yang cukup menarik. Sebelum adanya waduk, tampak bahwa nilai anak sangat berarti bagi orangtua khususnya dalam membantu pekerjaan mereka baik yang bersifat produktif maupun pekerjaan rumah tangga. Keadaan ini berubah sejalan dengan perubahan pola mata pencaharian pada keluarga. Anak sekarang sangat jarang terlibat dalam pekerjaan yang bersifat produktif, kecuali terdapat pada beberapa keluarga kasus yang merupakan keluarga lapisan bawah. Fenomena ini terjadi karena pekerjaan yang sekarang mereka geluti cukup beresiko (kegagalan) atau membutuhkan ketrampilan tertentu. Karena kini mata pencaharian sebagian besar dari mereka bukanlah pada bidang pertanian lagi tetapi perdagangan ataupun kegiatan jasa. Pada hampir seluruh responden kini melihat anak sebagai harapan untuk memperbaiki taraf kehidupannya kelak melalui jalur pendidikan. Hal itu tercermin dari meningkatnya tingkat pendidikan masyarakat Desa Wanadadi (seperti yang tertera pada Tabel 2), 


\section{Agriekonomika, ISSN 2301-9948

meskipun terdapat fenomena adanya beberapa anak yang putus sekolah karena faktor ekonomi utamanya. Padahal sesungguhnya mereka menginginkan anakanya untuk terus bersekolah supaya bisa meningkatkan taraf hidup keluarga kelak.

\section{PENUTUP}

Sejarah perubahan sosial di lokasi penelitian terjadi pada struktur masyarakat baik demografis maupun ekonomi. Perubahan pada kelembagaan masyarakat memperlihatkan makin menguatnya kelembagaan jasa dan perdagangan disamping perikanan. Juga ditandai dengan memudarnya lembaga tradisional yang biasanya hidup dalam masyarakat pertanian. Perubahan juga terjadi dalam nilai keluarga dan tipe ekonomi keluarga, serta pada nilai anak. Secara sosiologis, sebab-sebab timbulnya masalah dalam masyarakat adalah karena kelembagaan yang ada tidak berfungsi dengan baik. Oleh karena itu perlu dilakukan pembangunan kelembagaan (kelembagaan ekonomi maupun sosial) yang utuh dalam masyarakat di desa ini agar lembaga yang ada dapat berdaya dan bisa melaksanakan fungsi-fungsi yang diembannya. Perlu diadakan pembinaan dan penyuluhan yang berkesinambungan oleh pemerintah bersama masyarakat agar mereka dapat menghadapi perubahan yang terjadi. Pelatihan dalam peningkatan keterampilan, pengetahuan maupun pengalaman berusaha sangat dibutuhkan. Dibutuhkan dukungan dari birokrasi pemerintah dan lembaga keuangan yang baik agar dapat membantu masyarakat untuk pengembangan sektor ekonomi dan sosial.

\section{DAFTAR PUSTAKA}

Abidin, Rusdianto. 1997. Dampak Transformasi Lahan Pertanian Serta FaktorFaktor yang Berpengaruh Terhadap Kesempatan Kerja Sektor Pertanian. Skripsi. Jurusan IImu-IImu Sosial dan Ekonomi Pertanian. Fakultas Pertanian. Institut Pertanian Bogor. Bogor.

Anonim. 2010. Banjarnegara Dalam Angka 1980-1997. Bappeda Tk.II dan Kantor Statistik Kabupaten Banjarnegara. Banjarnegara.

Firdaus, Muhammad. 1995. Dampak Alih Fungsi Lahan Pertanian Terhadap Distribusi Pendapatan Mayarakat. Skripsi. Jurusan Ilmu-IImu Sosial dan Ekonomi Pertanian. Fakultas Pertanian. Institut Pertanian Bogor. Bogor.

Kasryno, Faisal, ed. 1984. Prospek Pembangunan Ekonomi Pedesaan Indonesia. Yayasan Obor Indonesia. Jakarta

Kusumaningrum, Juliman Foor Z, Dalvi Mustafa. 2015. Social Quality Masyarakat Lahan Pasir Pantai pada Aspek Social Empowernment di Kecamatan Panjatan Kabupaten Kulonprogo. Agriekonomika 4(1): 1-9.

Mubyarto. 1989. Pengantar Ekonomi Pertanian. Penerbit LP3ES. Jakarta.

Mubyarto. 1985. Peluang Kerja dan Berusaha di Pedesaan. Penerbit BPEF. Yogyakarta.

Rusli, Said. 1983. Pengantar Ilmu Kependudukan. Penerbit LP3ES. Jakarta.

Sajogyo, Pudjiwati. 1985. Sosiologi Pembangunan. Fakultas Pasca Sarjana IKIP dan BKKBN. Jakarta. 
Sajogyo, Pudjiwati. 1982. Modernisasi dan Perkembangan Sejarah Keluarga (The Family): Suatu Perspektif Mengenai Perubahan Sosial. Makalah Seminar Pengembangan Program dan Bidang Studi Pasca Sarjana/Pendidikan Kependudukan dan Lingkungan Hidup. Jakarta.

Soemardjan, Selo dan Soelaeman Soemardji. 1964. Setangkai Bunga Sosiologi. Yayasan Badan Penerbit Fakultas Ekonomi Universitas Indonesia. Jakarta.

Soemardjan, Selo. 1991. Perubahan Sosial di Yogyakarta. Gadjah Mada University Press. Yogyakarta.

Soentoro. 1983. Perkembangan Jumlah Rumah Tangga yang Mengusahakan Tanah Pertanian. Penerbit LP3ES. Jakarta.

Sumitro, Bambang. 1981. Sumbangan Tenaga Kerja Anak Terhadap Pendapatan Rumah tangga di Pedesaan. Tesis. Jurusan Sosiologi Pedesaan. Fakultas Pasca Sarjana. Institut Pertanian Bogor.

Susanto, S. Astrid. 1977. Pengantar Sosiologi dan Perubahan Sosial. Penerbit Binacipta. Bandung.

White, Benjamin dan Indrasari Tjandraningsih. 1991. Pekerja Anak dan Remaja di Pedesaan Jawa Barat: Pengantar Studi Lapangan. Makalah Lokakarya Masalah Pekerjaan Anak dan Remaja. Hasil Penelitian di Pedesaan Jawa Barat. Bogor. 